\title{
Lartetium africanum (Lavocat, 1961) (Eulipotyphla $\cdot$ Soricidae) from Beni-Mellal (Morocco), the oldest African shrew: new descriptions, palaeoenvironment and comments on biochronological context
}

\author{
Marguerite Hugueney $^{1}$ - Olivier Maridet ${ }^{2,3} \cdot$ Pierre Mein $^{1} \cdot$ Cécile Mourer-Chauviré $^{1}$. \\ Jérôme Priéto ${ }^{4}$
}

Received: 9 December 2014 / Accepted: 16 April 2015 /Published online: 13 June 2015

(C) Senckenberg Gesellschaft für Naturforschung and Springer-Verlag Berlin Heidelberg 2015

\begin{abstract}
Additional specimens of the poorly known African shrew Lartetium africanum (Lavocat, 1961) are described and complete our knowledge of this tiny animal. The results of this study justify the elevation of material originally described as a subspecies to the species rank. Soricids are hitherto unknown in older African localities. Like many other soricids, L. africanum lived in a rather humid habitat, close to a body of freshwater, as testified by the intercalations of travertines with reeds in the lacustrine lenses that yielded the fauna.
\end{abstract}

This article is a contribution to the special issue "Old worlds, new ideas. A tribute to Albert van der Meulen"

Olivier Maridet

olivier.maridet@jurassica.ch

Marguerite Hugueney

marguerite.hugueney@univ-lyon1.fr

Pierre Mein

pierre.mein@univ-lyon1.fr

Cécile Mourer-Chauviré

cecile.mourer@univ-lyon1.fr

Jérôme Priéto

j.prieto@1rz.uni-muenchen.de

1 Laboratoire de Géologie de Lyon: Terre, Planètes et Environnement, UMR 5276, Université Claude Bernard Lyon 1, 2 Rue Raphaël Dubois, 69622 Villeurbanne Cedex, France

2 Jurassica Museum, Route de Fontenais 21, 2900 Porrentruy, Switzerland

3 Department of Geosciences, Earth Sciences, University of Fribourg, Chemin du Musée 6/Pérolles, 1700 Fribourg, Switzerland

4 Department for Earth and Environmental sciences, Ludwig-Maximilian University Munich and Bavarian State Collections for Paleontology and Geology, Richard-Wagner Strasse 10, 80333 Munich, Germany
However, the presence of associated vertebrate taxa also attest to more open environments in the surroundings and a tropical climate. Various hypotheses on the date of arrival of this taxon in Africa have been proposed since migration routes between Eurasia and Afro-Arabia were not always open during the Middle Miocene and also because magnetostratigraphic data are now known and can be compared. These hypotheses are discussed here. Recent advances in our knowledge of the palaeogeography and the comparison of $L$. africanum with western European Lartetium taxa suggest that Beni-Mellal could be older than previously proposed, possibly early Middle Miocene.

Keywords Eulipotyphla - Soricidae - Crocidosoricinae · Middle Miocene - Northern Africa - Morocco - Faunal exchanges $\cdot$ Palaeoenvironment

\section{Introduction}

Lavocat (1961) studied the rich vertebrate fauna of BeniMellal (Morocco) and described, among a number of genera and species, a new soricid subspecies, Sorex dehmi Viret and Zapfe, 1951 africanus subsp. nov. He ascribed this soricid to the European species $S$. dehmi from the early Middle Miocene (MN5) locality of Vieux-Collonges (France, Rhône department) but noted a number of differences which justified the creation of the new subspecies. Ziegler (1989) subsequently assigned $S$. dehmi to his new genus Lartetium (known from MN3 to MN7/8 in Europe), with Sorex prevostianum from Sansan (MN6) being the genotype. Unfortunately, he did not mention the African subspecies. Some years later, Mein and Ginsburg (2002) suggested for the first time the elevation of the subspecies 'africanus' to the species level ('africanum'). 
The original material is poor (the holotype is now damaged and most of the teeth lost) and also insufficiently described and figured. Consequently, it does not provide sufficient insight into the morphology of this species. Fortunately, additional material from the type-locality, provided by Dr. J. Braillon to Lyon University, makes it now possible to improve our knowledge of this species, to justify the generic assignment of the species to Lartetium and to compare it more precisely with the other species of the genus.

Beni-Mellal is situated in a series of hills located at the base of the northern slopes of the Moroccan Atlas mountains. These hills consist of a succession of continental conglomeratic beds which lie unconformably on mesozoic deposits. Freshwater limestone lenses and travertines with reeds are interstratified within the conglomerates, and vertebrate fossil remains were found in these limestones (Choubert and FaureMuret 1961).

Lartetium from Beni-Mellal, together with Myosorex mentioned from the Ketchaba Formation in Tunisia dated at about 12 Ma (Butler 1998; Furió et al. 2007; Stoetzel 2013), constitute the first two occurrences of the family Soricidae in the Middle Miocene of Africa. Up to now, the Beni-Mellal fauna comprises almost exclusively African taxa, making it difficult to draw comparisons with Eurasian faunas and consequently to propose a correlation with the European mammal Neogene chronology (MN units; Mein 1975). However, the most recent age estimations of Beni-Mellal (Benammi 2006; Wessels 2009) indicate that Lartetium probably predates Myosorex in the African fossil record.

\section{Materials and methods}

The specimens described below are stored in the collection of University Lyon 1, Villeurbanne. They are catalogued under the numbers FSL 66873 to FSL 66880.

The classification used in this paper follows that of Furió et al. (2007). The nomenclature and measurements follow those proposed by Reumer (1984). For the dental formula we follow the recommendations of Dannelid (1998), counting 'upper/lower' incisors, antemolars, premolars and molars (e.g. genus Sorex: 1.5.1.3/1.1.1.3).

For each measurable tooth the length and width are provided under the form: 'length' $\times$ 'width'; other dental measurements are the maximum length (L), the maximum width (W) and the maximum height $(\mathrm{H})$. Other measurements are according to Reumer (1984) and are indicated in the text. All measurements are given in millimetres.

\section{Abbreviations}

Institutions: $\mathrm{FSL}=$ Collection of the University Lyon 1; $\mathrm{MNHN}=$ Natural History Museum of Paris; SMNS=
Staatliches Museum für Naturkunde, Stuttgart; SNSB$\mathrm{BSPG}=$ Staatliche Naturwissenschaftliche Sammlungen Bayerns, Bayerische Staatssammlung für Paläontologie und Geologie, Munich.

Teeth: I, i=incisor; A, a =antemolar; $\mathrm{P}, \mathrm{p}=$ premolar; $\mathrm{M}, \mathrm{m}=$ molar. Uppercase letters indicate upper teeth; lowercase letters indicate lower teeth.

Other abbreviations: $\mathrm{Mx}=$ maxilla; $\mathrm{Md}=$ mandible.

\section{Systematic palaeontology}

Order Eulipotyphla Waddel, Okada and Hasegawa, 1999

Family Soricidae Fischer, 1814

Subfamily Crocidosoricinae Reumer, 1987

Tribe Oligosoricini Gureev, 1971

Genus Lartetium Ziegler, 1989

Diagnosis (Ziegler 1989: 48; translated from German): Small to medium-sized Crocidosoricine with four lower antemolars. Mental foramen under the $\mathrm{p} 4$. Mandibular foramen under the middle of the fossa pterygoidea. Lower antemolars (a1-a3) single rooted, a3 very small. Fourth lower antemolar (a4 or p4) with two roots, with two distal crests, that ends at the half of the crown's height. Hypoflexid of the lower molars low. Labial cingulum of the $\mathrm{m} 1+2$ higher under the protoconid or interrupted. Conical entoconid, no entocristid. Hypolophid ending free, just behind the entoconid. M1 +2 with free-ending protocone posterior arm and well-developed 'hypocone'.

Type species: Lartetium prevostianum (Lartet, 1851)

Locus typicus: Sansan (France); early Middle Miocene (MN6).

Remarks: The differential diagnosis provided by Ziegler (1989) took into account Crocidosorex, but not Oligosorex which was at that time considered to be a junior synonym of Crocidosorex (which has changed with the proposal of Van den Hoek Ostende 2001). As illustrated by the close phylogenetic relationship between Lartetium and Oligosorex (Hugueney and Maridet 2011), both genera are difficult to distinguish because they display an identical lower dental formula (but a supplementary upper antemolar in Oligosorex), and the morphology of their molars is not very different. A number of recent studies actually do not discriminate between these two genera in palaeoecological models (see, for example, Furió et al. 2011), with some authors claiming a revision of both genera (see, for example, Klietmann et al. 2014).

However, in addition to the differential characteristics described by Ziegler (1989) for Lartetium, the corpus mandibulae is more massive in Lartetium but slender with a more elongated incisor in Oligosorex; the $\mathrm{m} 1$ of Lartetium have an asymetrical trigonid (the paralophid being stretched 
instead of the subequal crests of Oligosorex), and the oblique crest is much more labial in $\mathrm{m} 1$ than in $\mathrm{m} 2$ (instead of being similar as in Oligosorex), with the hypolophid ending closer to the conical entoconid in Lartetium and the talonid of $\mathrm{m} 3$ being more reduced in length; the lower molars of Oligosorex are not transversely stretched and more rectangular.

Doukas and Van den Hoek Ostende (2006) also noted that although Ziegler (1989) mentions the absence of entocristids in the diagnosis of the genus Lartetium, this absence should be nuanced because a weak crest is present in Lartetium dehmi, L. prevostianum (and L. africanum as well). Cranial characteristics are to be noted: in lateral view there is an angle of $130^{\circ}$ between the anterior part of the maxilla and the posterior part with molariform teeth in Lartetium; in Oligosorex this angle is $150^{\circ}$ (Stehlin 1940: fig. 4b). On the palate, Lartetium shows three large and triangular anterior foramina; in contrast, these are small and rounded in Oligosorex. Lartetium has four antemolars before $\mathrm{P} 4$ and Oligosorex has five. The M1-M2 of Lartetium are much wider than long, but in Oligosorex they are not transversely extended and are squarer. The P4 and M1 of Oligosorex lack the hypocone, the preprotocrista of M1 is longer than that of Lartetium and extends farther onto the base of the paracone.

\section{Lartetium africanum (Lavocat, 1961) (Figs. 1, 2)}

1961 Sorex dehmi Viret and Zapfe, 1951 africanus subsp. nov. Lavocat, p.77, pl. 8, fig. 3.

1994 Lartetium dehmi africanus Reumer, p. 354, tab. 4.

1998 Lartetium dehmi africanus Butler, p. 121.

1999 Lartetium dehmi africanum Vergilino, p. 8.

2002 Lartetium africanum (Lavocat, 1961) Mein and Ginsburg, p. 22.

2007 Lartetium africanum Furió et al., p. 1030.

2010 Lartetium dehmi africanum Butler, p. 574, tab. 29.2.

2013 Lartetium dehmi Stoetzel, p. 363.

Holotype: Right mandible with $\mathrm{m} 1-3$ and four unicuspides (MNHN Ben. Mel. 1165). The specimen is now damaged, and all of the teeth are missing.

Locus typicus: Beni-Mellal (Morocco); Middle Miocene (see discussion below).

Original diagnosis: Lavocat (1961: 77; translated from French) "subspecies differing principally from (L. dehmi) by its smaller size".

Emended diagnosis: Small-sized soricid with a large expansion of labial cingulids on lower molars; $\mathrm{m} 1$ with a talonid that is much wider than the trigonid; $\mathrm{m} 3$ with a talonid basin where the oblique crest points to the base of the metaconid; transversely stretched P4 and M1 display a more or less small hypocone and show a strong posterior emargination. I with pigmented tip.

Differential diagnosis: Lartetium africanum differs from L. dehmi in being smaller and in having a shorter and wider $\mathrm{m} 1$ and $\mathrm{m} 3$ with a strongly oblique crista obliqua. P4-M1 with a longer metastyle and a stronger emargination on the posterior edge. Lartetium africanum differs from $L$. prevostianum, which is approximately of the same size, by the wider talonid of $\mathrm{m} 1-2$, the different talonid of $\mathrm{m} 3$ and the stronger posterior emargination of P4-M1. More generally, L. africanum differs from all other European Lartetium and Miosorex species in being smaller and in having the oblique crest of $\mathrm{m} 3$ convergent to the entoconid crest in the talonid basin.

\section{Additional material and measurements:}

- Right mandible with p4-m3 (FSL 66873): L p4-m3= 4.25; $\mathrm{L} \mathrm{m} 1-\mathrm{m} 3=3.47 ; \mathrm{p} 4=0.91 \times 0.63 ; \mathrm{m} 1: \mathrm{L}=1.26 \times$ TRW $($ trigonid width $)=0.83 \times \mathrm{TAW}($ talonid width $)=0.93$; $\mathrm{m} 2: \mathrm{L}=1.28 \times \mathrm{TRW}=0.82 \times \mathrm{TAW} 0.91 ; \mathrm{m} 3=1.08 \times 0.61$.

- Left mandible with the base of incisor, antemolars alveoli and p4-m3 (FSL 66874); L p4-m3=3.95; L m1-m3= $3.23 ; \mathrm{p} 4=0.70 \times 0.64 ; \mathrm{m} 1: \mathrm{L}=1.20 \times \mathrm{TRW}=0.80 \times$ $\mathrm{TAW}=0.88 ; \mathrm{m} 2: \mathrm{L}=1.30 \times \mathrm{TRW}=0.78 \times \mathrm{TAW} \times 0.85$; $\mathrm{m} 3=1.0 \times 0.62$.

- Left mandible fragment with $\mathrm{m} 1$ (FSL 66875): $\mathrm{L}=1.28 \times$ $\mathrm{TRW}=0.87 \times \mathrm{TAW}=0.93$.

- Right lower incisor (FSL 66876): $\mathrm{L}=1.98 ; \mathrm{H}=0.64$.

- Right maxillary fragment with P4 and alveoli of A3-A2A1 (FSL 66877): P4: BL (buccal length) $=1.47 \times \mathrm{W}=$ 1.25 .

- Right maxillary fragment with M1 (FSL 66878): M1: $\mathrm{BL}=1.33 \times \mathrm{PW}($ posterior width $)=1.73$.

- Right upper incisor (FSL 66879): $\mathrm{L}=1.39 ; \mathrm{H}=1.08$.

- $\quad$ Right M1 (FSL 66880): M1: BL=1.21× PW=1.72.

\section{Description}

Lower dentary: The mandible is small but with a relatively high corpus mandibulae of which only the base of the ascending ramus is preserved. The mental foramen is under the posterior root of $\mathrm{p} 4$; the mandibular foramen is very posteriorly located. The root of the incisor ends under the trigonid of $\mathrm{m} 1$ where the posterior symphyseal foramen is clearly visible. The horizontal ramus is clearly concave under the posterior root of the $\mathrm{m} 1$. The ascending ramus and the condyle are not preserved. The lower incisor is bicuspulate with a very tiny secondary cuspule (similar to that of Lartetium prevostianum figured by Engesser 2009). The p4 is biradiculate with a Vshaped tip, two distal crests that end at the half of the crown's height and a posterior sulcus; it possesses a large cingulum which almost circles the tooth and only disappears at the anterior end. On the two mandibles, the $\mathrm{m} 1$ is about the same size as the $\mathrm{m} 2$ or only a little shorter. The cingula, with the exception of the lingual one, are well marked, posteriorly enlarged and even more so anteriorly; they are a little undulated 


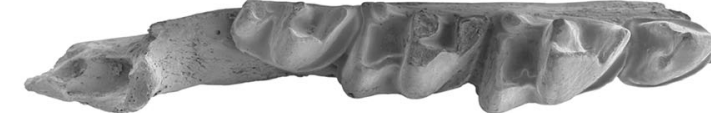

$1 a$
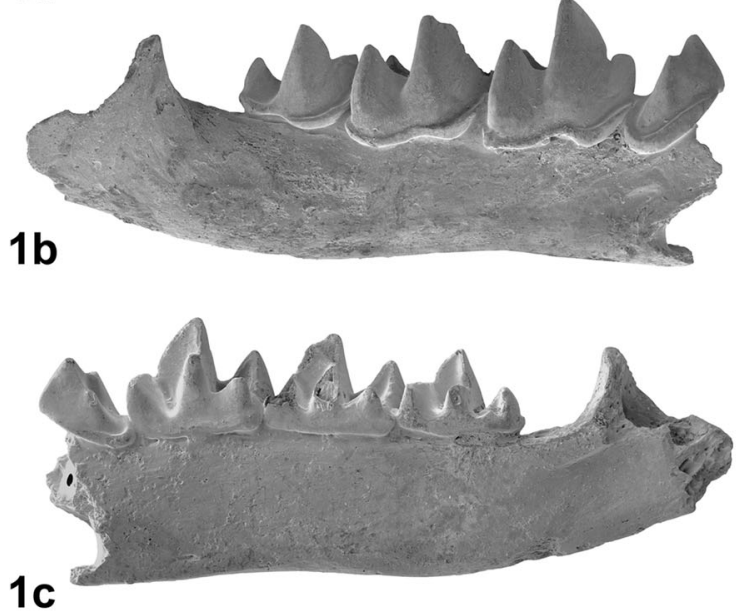

$2 a$
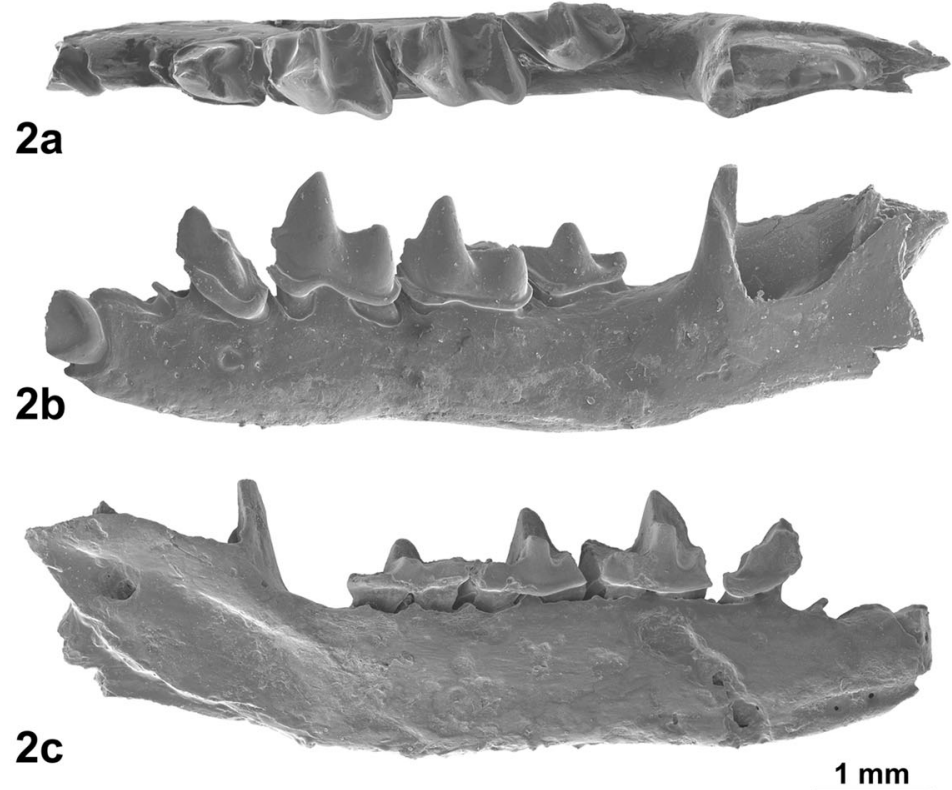

Fig. 1 Lartetium africanum Lavocat, 1961 from Beni-Mellal. 1 right mandible with p4-m3, FSL66873 (1a occlusal view; 1b labial view, 1c lingual view), 2 left mandible with p4-m3, FSL66874 (2a occlusal view, 2b labial view, 2c lingual view)

under the protoconid. The entoconid is conical in shape and strong; it appears to be sub-isolated due to the well-indented crest of the entoconid. The hypolophid runs behind the base of the entoconid and ends isolated. The labial faces of the tubercles are bulbous. The $\mathrm{m} 1$ is characterised by its very wide talonid and the very labial crista obliqua; this crest ends a little more lingually on $\mathrm{m} 2$. The talonids of $\mathrm{m} 1-2$ are not very reduced in length. The $\mathrm{m} 3$ is smaller but similar to the other molars except for its reduced talonid; the crista obliqua runs directly to the base of metaconid and is confluent with the low entoconid crest, the entoconid being nearly absent.

Upper dentary: A right fragment of maxillary with M1 shows the infra-orbital foramen; in labial view, the infraorbital foramen opens above the mesostyle of the M1, but the bridge of the canalis infraorbitalis is short and ends posteriorly above the posterior part of this M1. The lacrimal foramen is oval (higher than long) and situated on the upper part of the bridge (Fig. 2c). The upper incisor is small and strongly curved on the anterior edge, with pigmentation visible on the tips of the two cusps. Antemolars are not preserved, but on the right maxillary with P4 (FSL 66877), three alveoli are visible before the maxillary break, the posterior one being the smallest. The upper teeth are transversely stretched and strongly emarginated posteriorly, with a marked hypocone. The P4 has a long metastyle and a well-individualised antero-labial parastyle located at the labial end of the anterior cingulum. A smaller and more posterior cuspule can be identified as the protocone due to its longitudinal postprotocrista. There is also a large posterior emargination with a continuous faint cingulum on the posterior edge, ending in the hypocone. The M1 possesses an anterior protocone linked to the paracone by a preprotocrista that ends at the base of paracone; the postmetacrista is very long; the hypocone is well-developed and located at the end of the posterior cingulum. There are two labial roots on the M1, two lingual roots and a smaller central root. Another M1 (FSL 66880) is morphologically similar, but its hypocone is nearly indistinct. M2 and M3 are absent in the Lyon collection.

Discussion: The first specimens of soricid found in BeniMellal were identified by Lavocat (1961) as a subspecies of Sorex dehmi-S. dehmi africanum. In his description Lavocat (1961) provided the following main morphologic characteristics: four lower antemolars (three unicuspids before the biradiculate $\mathrm{p} 4$ ), with the minute a3 being even more squeezed between the $\mathrm{p} 4$ and a2 than in $S$. dehmi; the mental foramen located under the posterior root of $\mathrm{p} 4$; the talonid of the $\mathrm{m} 1$ strongly developed transversely; the p4 displaying V-shaped crests; a well-developed basal cingulum.

When Ziegler (1989) proposed his diagnosis of the genus Lartetium, he included the species 'Sorex' dehmi, but he did not mention the African subspecies. Lavocat's (1961) description of the subspecies of Beni-Mellal is in accordance with the diagnosis of Lartetium, especially in terms of the strong transversal development of the talonid of $\mathrm{m} 1$ [despite some variability and the fact that Ziegler (1989) did not take into account the transversal aspect in his diagnose] and the welldeveloped hypocone of M1. It is however noteworthy that the strong development of the talonid in $\mathrm{m} 1$ and the pigmentation are not present in L. petersbuchense, but characteristic of L. dehmi. Although the ascending ramus, the condyle and 


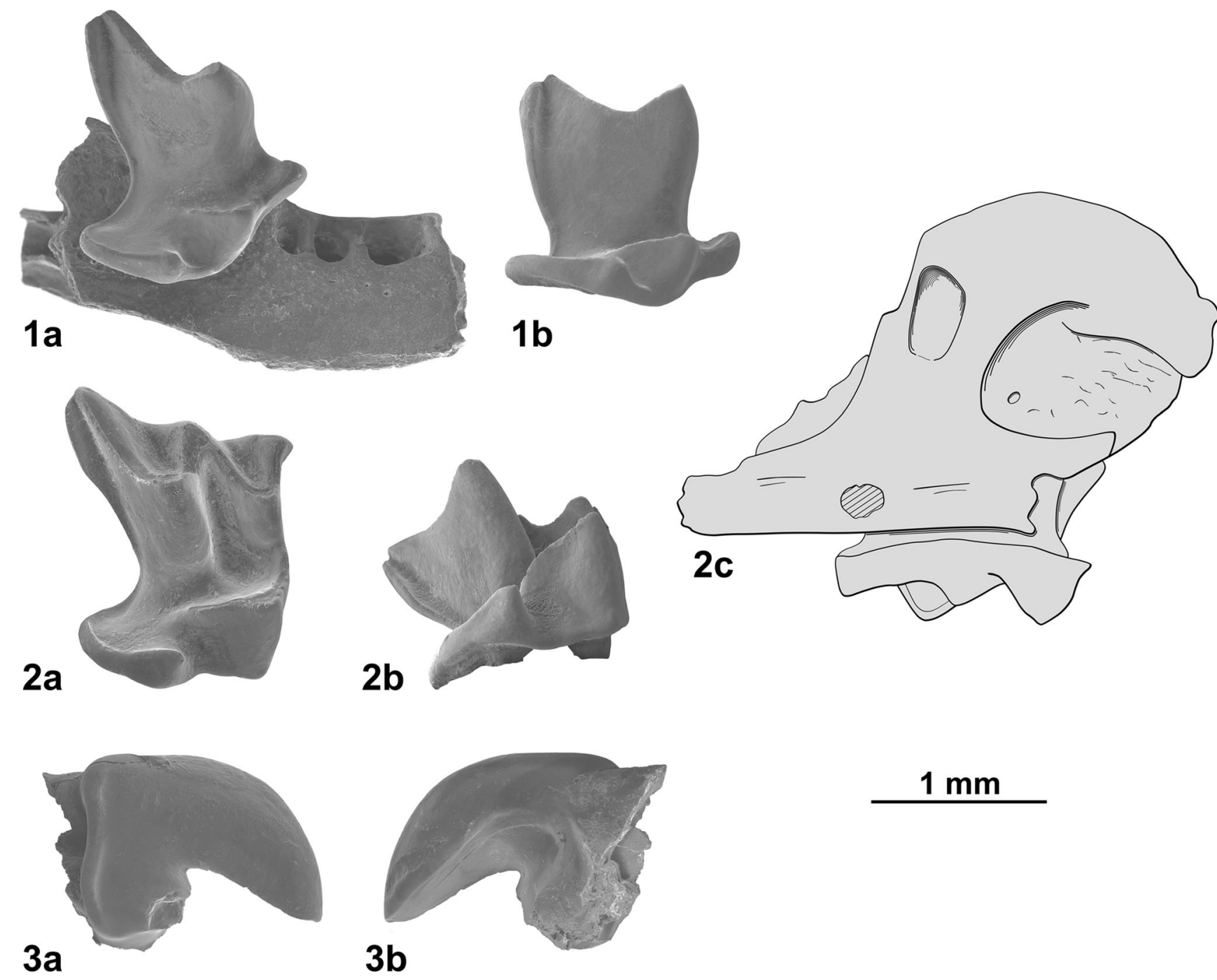

Fig. 2 Lartetium africanum Lavocat, 1961 from Beni-Mellal. 1 Right max. with P4, FSL66877 (1a occlusal view, 1b lingual view), 2 right max. with M1, FSL66878 (2a occlusal view, 2b lingual view, 2c sketch drawing, labial view of the max.), 3 right I, FSL66879 (3a labial view, 3b lingual view)

the anterior part of the maxilla are unknown in the specimens from Beni-Mellal, this African soricid shares many characteristics with $L$. dehmi from Vieux-Collonges. The number of lower antemolars, the morphology of the $\mathrm{p} 4$, the position of the mental foramen and the configuration of teeth and cingula confirm its attribution to the genus Lartetium, as previously proposed by Butler (1998), Mein and Ginsburg (2002) and Stoetzel (2013).

The morphological differences mentioned in the differential diagnosis (see above) justify the separation of the genera Lartetium and Oligosorex and exclude the proposal that the form from Beni-Mellal could belong to the genus Oligosorex. The differences with the other Lartetium species justify erecting the subspecies from Beni-Mellal to species rank. Lartetium africanum is likely the oldest species of Lartetium known to date and consequently the oldest species of soricid recorded in Africa (Butler 2010). It is also as small as $L$. prevostianum from Sansan (type locality of $L$. prevostianum, which is the type of the genus) (Table 1). It is thus noteworthy that there is no lineal evolutionary trend in size within the genus - both the oldest and the youngest species are larger than the intermediate ones.

\section{The fossil record of Lartetium}

Lartetium is mainly a European genus. In France, this taxon has only been reported in a few localities, but in those sites where it is present, material is usually abundant and described in publications. Sansan is the type locality of $L$. prevostianum, type species of the genus [see Engesser (2009) for a detailed study of this population]. Lartetium prevostianum is mentioned (as Oligosorex) in the faunal list of Lo Fournas II (MN6; Aguilar et al. 1986).

Vieux-Collonges is the type locality of $L$. dehmi specimens, which are described by Hugueney et al. (2012). Lartetium 
Table 1 Comparison of the length of the lower tooth row (m1-m3) of Lartetium for six western European localities and L. africanum from Beni-Mellal

\begin{tabular}{llrlll}
\hline Minimum-maximum $(\mathrm{mm})$ & Mean $(\mathrm{mm})$ & $N$ & Species & Locality & Age \\
\hline $3.73-3.85$ & 3.79 & 2 & L. ziegleri & La Grive L3 & MN7/8 \\
$3.30-3.39$ & 3.34 & 2 & L. prevostianum & Sansan & MN6 \\
$3.85-4.18$ & 3.98 & 14 & L. dehmi & Steinberg & MN6 \\
$3.23-3.47$ & 3.35 & 3 & L. africanum & Beni-Mellal & MN5-6? \\
$3.61-4.00$ & 3.75 & 48 & L. dehmi & Vieux-Collonges & MN5 \\
$3.73-4.01$ & 3.88 & 5 & L. petersbuchense & Petersbuch 2 & MN4 \\
$3.55-4.11$ & 3.91 & 24 & L. petersbuchense & Petersbuch 28 & MN3-4 \\
$2.97-3.23$ & 3.11 & 20 & L. cf. prevostianum & Petersbuch 28 & MN3-4 \\
\hline
\end{tabular}

The two last columns indicate the localities and their correlations with the European Mammalian biozonation. The measurements of L. prevostianum from Sansan are taken from Engesser (2009), those from La Grive and Vieux-Collonges are from Hugueney et al. (2012) and those from Petersbuch 28 are from Klietmann et al. (2014); other measurements have been made in the framework of this publication ziegleri is known from La Grive L3 (Mein and Ginsburg 2002; Hugueney et al. 2012).

In Germany, there are many localities with fossils of Lartetium, but apart from some rich localities, the specific ascription of the remains is most often difficult because the material is frequently too poor. Ziegler (2006) lists L. petersbuchense in Petersbuch 2 (the type locality) and Erkersthofen 2 (MN4). Klietmann et al. (2014) recently listed two Lartetium species in the Bavarian fissure filling Petersbuch 28 (ascribed to MN3-4, a little older than Petersbuch 2 but with evident age mixing). The first of these is $L$. petersbuchense, which is approximately similar in size to the type species. The second is $L$. cf. prevostianum, a minute form which curiously in this site is represented by 54 mandibular fragments, some of which very well preserved but without any upper maxillary or upper teeth. This material suggests the presence of two lineages of Lartetium - a large sized and a smaller oneand the possibility of size enlargement in the smaller species. Further studies on this material will be necessary to specify the evolutionary interpretation based on these two forms.

Lartetium dehmi is recorded in Petersbuch 2 (MN4), Langenau 1 (MN4), Puttenhausen (MN5), Gallenbach 2c (for comparison) and Steinberg (MN6). Well-preserved and mostly unstudied material from Steinberg is stored in the SNSB-BSPG and SMNS and includes skulls and mandibles; however, these specimens have not yet been described (neither have most of its fossil fauna). Consequently, the dating of the locality is restricted to data available from the literature. Heizmann and Fahlbusch (1983) originally listed Cricetodon sansaniensis, which temporally links the locality to Sansan (MN6), but this assignment is corrected by (Heissig 1989) as C. aff. jotae and emended by Sach (1999), Rummel (2000) and Rummel and Kälin (2003), who recognised $C$. aff. aureus. This emended designation points to an older age than that of Sansan.
Abundant material of $L$. dehmi has also been identified by Ziegler and Fahlbusch (1986) in Forsthart (MN4). However, after direct inspection of this material it can be stated that the lower incisor differs from that figured by Hugueney et al. (2012: fig. 7F) from Vieux-Collonges (the type locality of L. dehmi). This material probably needs a revision and should be better considered in the meantime as Lartetium sp., as so should the few remains from Rembach and Raucheröd (MN4). Finally, Sach (2014) lists the presence of L. dehmi in Untereichen-Altenstadt (MN6), although this species was not observed by Prieto et al. (2009).

In the rest of Europe, the occurrences of Lartetium are rather scattered over time and space. In Austria, L. cf. prevostianum has been reported by Ziegler (1998) in Oberdorf 3 (MN4). In the Czech Republic, Fejfar and Sabol (2005) listed $L$. cf. petersbuchense in the faunal assemblage from Merkur-Nord (MN3). In the Slovac Republic, L. dehmi is recorded in Devínská Nová Ves (Fejfar and Sabol 2005), although Hugueney et al. (2012) do not agree with this identification. In Serbia, L. dehmi is listed in the old collections of Sibnica (MN4), but its presence was not confirmed by the new finds of Sibnica 1 (Marković and Milivojević 2010). In Greece, a few isolated teeth ascribed to L. cf. dehmi by Doukas and Van den Hoek Ostende (2006) were found in Karydia (MN4/5). In Anatolia, two isolated lower molars from Çandir (MN5) belonging most probably to one individual closely resemble those of Lartetium dehmi according to Engesser (1980). Van den Hoek Ostende (2001: 50) suspects that Lartetium is present in Semsettin (MN4) but that the material is limited to a single M1. Similarly, he recognises some Lartetium morphological features in the soricid I and II from Kilçak and Harami (MN2) and Kesekoy (MN3). Evidently, the Anatolian material is too poor to clearly demonstrate the presence of the genus. Finally, in Spain, López-Guerrero et al. (2007) reported the presence of Lartetium sp. in Casa Montero (MN5), but the remains were not described. 
Although the occurrence of Lartetium in eastern Europe, the Balkans, Anatolia and Spain is reported from MN3 to MN6, the scarcity of the material and information does not allow further comparisons with $L$. africanum. It is also noteworthy that La Grive L3 is the only late Middle Miocene locality in western Europe where Lartetium has been identified. Other than that, the genus is restricted to the Early and early Middle Miocene.

In northern Africa, apart from Beni-Mellal, Pickford et al. (2008) reported Lartetium sp. from the Late Miocene of Sheikh Abdallah (Central Egypt, MN9). Moreover, Stoetzel (2013) states that L. dehmi occurs up to her local Biozone 4 in the Late Miocene localities Oued Zra (MN9) and Khendek el Ouaich (MN13) in Morocco, which would be the youngest records of the genus to date. However, the only cited reference for these localities is an unpublished Master's dissertation (Vergilino 1999) in which only the material from Oued Zra is figured (P4, A2?, M3, p4, I, m3), with correspondence to the characteristics of $L$. africanum. The material of Khendek el Ouaich consists only of a unique $\mathrm{ml}$ which is neither described nor figured. To date, the only published reference identifies these occurrences as Soricidae indet. (Jaeger 1977). Finally, Tesón et al. (2010) cited and figured the presence of an Oligosoricini shrew ('Lartetium-like') in Late Miocene sediments from Ouarzazate basin (Morocco). The $\mathrm{ml}$ and the i illustrated by Tesón et al. (2010) could also correspond to Lartetium but, as noticed by Engesser (2009), isolated teeth, especially in Lartetium, are often difficult to ascribe with certainty. In any case, reports on the occurrence of Lartetium in the Late Miocene of Morocco must be taken with caution.

\section{Palaeoenvironmental data}

The majority of the Beni-Mellal mammals (particularly the terrestrial sciurid Atlantoxerus, the semi-hypsodont pedetid Megapedetes, the Myocricetodon species which are thought to have given rise to extant gerbillids, the hyracoid) are considered to be associated with open areas and a relatively dry climate (Jaeger 1977). However, a savanna environment is needed to sustain the diversity of large mammals found in Beni-Mellal (giraffids, suids, bovids). Furthermore, the glirid Dryomys and the soricid Lartetium hint at a certain degree of humidity (Daams and Van der Meulen 1984; Reumer 1995; Furió et al. 2011) with some bushes and/or trees associated with herbs. Two species of bats belong to the genus Megaderma which lives today in tropical environments. One of the birds, Bucorvus brailloni, a fossil calao, is ascribed to an extant genus (Brunet 1961, 1971); the genus Bucorvus lives at present only in Africa south of the Sahara. Two extant species are known, one of which lives in savannas with subdesertic bushes and the other in more humid woodlands; however, it is not possible to further interpret the ecology of Bucorvus brailloni with regard to these extant taxa. A diversified and numerous assemblage of Amphibians and squamates are present at Beni-Mellal (Hecht et al. 1961; Hoffstetter 1961; Rage 1976), which also indicates humid habitats. The whole faunal assemblage (Table 2) consequently suggests a mosaic environment that includes a humid tropical savanna woodland, probably around a body of freshwater (as indicated by the fossiliferous freshwater limestone lenses and travertines with reeds of the locality), and more open and drier grassland in the surroundings.

\section{Chronological considerations}

The fauna of Beni-Mellal has yielded a large majority of endemic African taxa (see faunal list in Table 2), thus precluding direct faunal comparisons with European faunas. Moreover, and particularly in the Middle Miocene, the correlations between European faunas themselves and the MN scale used in European mammal chronology are disputed. This is principally because Spanish faunas are different from the other Middle Miocene European ones (Sen 1997; Van der Meulen et al. 2011; 2012; Reichenbacher et al. 2013), so the attribution to $\mathrm{MN}$ units is not straightforward.

The Beni-Mellal locality was originally assigned to the MN7/8 level (Mein 1975). However, the increasing body of knowledge on the late Middle Miocene faunas and migrations indicates that this locality might be older. Indeed, during this time interval no connection between Africa-Arabia and Eurasia has been demonstrated (Meulenkamp and Sissingh 2003; Wessels 2009). Furthermore, the ctenodactylid rodents of Beni-Mellal (Metasayimys, Africanomys) are shown to be derived from an Asian Early Miocene ancestor which probably arrived via an Early Miocene corridor between Eurasia and Afro-Arabia (López-Antoñanzas and Knoll 2011).

With regard to this problem, the Greek locality Chios (including the three fossiliferous horizons Thymiana $\mathrm{a}, \mathrm{b}$ and c; Koufos 2006) is of particular importance because it records the presence of Eurasian faunal elements, particularly rodents (e.g. Cricetodon meini, Megacricetodon primitivus, Democricetodon gracilis in De Bonis et al. 1997), the age of which corresponds to MN5 level, associated with AfricanArabian rodents (Megapedetes aegaeus, thryonomyid). De Bonis et al. (1997) and López-Antoñanzas et al. (2005) report for Chios a magnetostratigraphic age correlated to chron C5Br, corresponding to 15.97-15.2 Ma (Hilgen et al. 2012). This early Middle Miocene age estimate is in agreement with a correlation with the MN5 biozone.

Although Megapedetes is only known from a few teeth in Beni-Mellal, Sen (1977) noticed a stronger morphological similarity with M. aegaeus Sen, 1977 from Anatolia rather than with M. pentadactylus MacInnes, 1957 from eastern 
Table 2 Updated faunal list of mammals and birds from Beni-Mellal (Morroco), including the synonymies with the original faunal lists published in Lavocat (1961) and Brunet (1961)

Mammalia

Chiroptera

Megadermatidae: Megaderma gaillardi Trouessart, 1897-1905 (=Afropterus gigas n.g., n.sp. Lavocat, 1961)

Megaderma jaegeri Sigé, 1976 (=Cheiroptère sp. in Lavocat 1961)

Rhinolophidae: Rhinolophus mellali Lavocat, 1961 (=Rhinolophus ferrum-equinum mellali $\mathrm{n}$. ssp. Lavocat, 1961)

Hipposideridae: Hipposideros (Syndesmotis) vetus (Lavocat, 1961) (=Asellia vetus n. sp. Lavocat, 1961)

Molossidae: Tadarida engesseri Rachl, 1983 (=Molossidae indet. in Lavocat 1961)

Vespertilionidae indet.

Eulipotyphla

Erinaceidae: Mellalechinus salis (Lavocat, 1961) (= Protechinus salis in Lavocat 1961; + Palaeoerinaceus? in Lavocat 1961)

Schizogalerix sp. ?

Soricidae: Lartetium africanum (Lavocat, 1961) (=Lartetium dehmi africanum nov. subsp.)

Lagomorpha

Ochotonidae: Austrolagomys mellali n.sp. (Janvier and de Muizon, 1976) (=Kenyalagomys)

Rodentia

Sciuridae: Atlantoxerus tadlae (Lavocat, 1961) (=Getuloxerus tadlae n.g., n.sp. =Atlantoxerus huvelini unpublished)

Gliridae: Dryomys ambiguus n.sp. Lavocat, 1961(Afrodyromys=junior synonym in Daams and De Bruijn 1995)

Ctenodactylidae: Metasayimys curvidens n.g., n.sp. Lavocat, 1961 [=Sayimys jebeli n.sp. Lavocat, 1961; =Africanomys incertus (partim) and Africanomys pulcher (partim); = Dubiomys mellali n.g., n.sp Lavocat, 1961]

Africanomys pulcher n.g., n.sp (Lavocat, 1961) [A. incertus (partim) Lavocat, 1961]

Pedetidae : Megapedetes cf. aegaeus Sen, 1977 (= Megapedetes sp. in Lavocat 1961)

Thryonomyidae: Paraphiomys occidentalis n.sp. Lavocat, 1961

Gerbillidae, Myocricetodontinae: Myocricetodon parvus n.sp. (Lavocat, 1961) (=Cricetodon parvus n.sp. in Lavocat 1961)

Myocricetodon cherifiensis n.g., n.sp. Lavocat, 1952

Mellalomys atlasi (Lavocat, 1961) (=Cricetodon atlasi n.sp. in Lavocat 1961)

Dakkamys zaiani Jaeger, 1977

Fissipeda

Ursidae: Agnotherium cf. antiquum Kaup, 1833

Mustelidae: Martes khelifensis n.sp. Ginsburg, 1977

Mellalictis mellalensis n.g., n.sp. Ginsburg, 1977

Viverridae: Genetta sp.

Hyaenidae: Ictitherium cf. arambourgi Ozansoy, 1965

Hyaenictis graeca Gaudry, 1862-67

Felidae: Felis nov. sp.

Proboscidea

Proboscidea indet.

Perissodactyla

Rhinocerotidae: cf. Paradiceros mukirii Hooijer, 1968

Artiodactyla

Suidae: Listriodon juba n.sp. Ginsburg, 1977

Giraffidae: Palaeotragus lavocati n.sp. Heintz, 1976 (= Giraffidae indet. in Lavocat 1961)

Bovidae: Benicerus theobaldi n.g., n.sp. Heintz, 1973 (= Bovidae indet. in Lavocat 1961)

Hyracoïdea

Pliohyracidae: Parapliohyrax mirabilis n.g., n.sp. Lavocat, 1961

Aves

Phasianidae : Miogallus ? sp. (=Gallus sp. in Brunet 1961)

Tytonidae:Tyto alba (Scopoli, 1769) (=Asio flammeus Pont., 1763 in Brunet 1961)

Bucerotidae: Bucorvus brailloni Brunet, 1971

Miopiconidae: Miopico benimellalensis Mayr, 1998 (=Jynx cf. torquilla Linné, 1758 in Brunet 1961)

Muscicapidae: Luscinia cf. megarhynchos Brehm, 1831 
Africa (Fort Ternan and Maboko, Kenya; Winkler 1992). As stated by Jaeger (1977) and Stoetzel (2013), the occurrence of Megapedetes in Beni-Mellal is probably an Early Miocene North African tropical element that persisted into the Middle Miocene. In any case, this assemblage testifies to exchanges between Anatolia and Africa during the early Middle Miocene and suggests that the faunal assemblage of Beni-Mellal could be older than previously proposed. Furthermore, the size and morphology of the soricid L. africanum also suggest that it could be more closely related to early Middle Miocene European Lartetium, such as L. dehmi from VieuxCollonges (MN5) or Steinberg (MN6 in Heizmann and Fahlbusch 1983) and particularly to L. prevostianum from Sansan (MN6).

Sen (1997) correlated the succession of polarity of Sansan to the Chrons C5ADr-C5Br corresponding to an age between 14.8 and 15.2 Ma. As discussed by Maridet and Sen (2012), the faunal assemblage of Sansan, the body-mass composition of the community and the high species richness of cricetids, all indicate a subtropical environment. Consequently, Sansan may not be younger than the mid-Miocene event, which is a significant drop in global temperature occurring between 14.7 and 13.9 Ma (e.g. Flower and Kennett 1994; Holbourn et al. 2007). Kälin and Kempf (2009) and Van der Meulen et al. (2011) have already stated that the age estimation of Sansan (Chron C5ABn, around $13 \pm 0.5 \mathrm{Ma}$ ) proposed by Daams et al. (1999) and Pickford (2012) is too young, suggesting instead a correlation to the lower part of chron C5ACn (approx. $14 \mathrm{Ma}$ ). Based on the mid-Miocene climatic change, the age estimations of approximately $14 \mathrm{Ma}$ for Sansan also seem to be slightly too young, thus rather supporting an age estimation noticeably older than $14 \mathrm{Ma}$.

All of the previous observations based on the fauna consequently suggest that Beni-Mellal could be early Middle Miocene (Langhian), close to the ages of Chios, VieuxCollonges, Steinberg or Sansan, roughly between 15.0 and 14.5 Ma, which correlates in Europe either to MN5 or MN6 depending on the region considered (Kälin and Kempf 2009; Van der Meulen et al. 2011). However, this interpretation is in contradiction with the results of recent magnetostratigraphic studies in Morocco which propose a late Middle Miocene (Serravallian) age for Beni-Mellal at either around 13.2 Ma (Benammi 2006) or around 14-13 Ma (Benammi et al. 1996; Werdelin 2010). If Beni-Mellal is considered to be late Middle Miocene (Serravallian), Megapedetes would be the result of an old migration and would have persisted during the whole early and late Middle Miocene. Therefore, Lartetium and Dryomys would have persisted up to the Late Miocene in the absence of competition with similar genera (Wessels 2009). This hypothesis is coherent with a certain degree of endemicity observed by Jaeger (1977) in the Miocene faunas of Northern Africa.
Nonetheless, the first hypothesis proposed above, which is based on our comparisons of $L$. africanum with western European species and on our improved knowledge of the palaeogeographical and palaeobiogeographical contexts (e.g. Meulenkamp and Sissingh 2003; Koufos et al. 2005; Wessels 2009) and palaeoclimatic context, has also to be considered. Beni-Mellal could be early Middle Miocene (Langhian) and equivalent to the European biozones MN5-MN6, which would imply that the magnetostratigraphic correlation needs to be revised. In this case the occurrence of Megapedetes, Lartetium and Dryomys in Beni-Mellal would reflect ongoing extensive faunal exchanges with the Arabic plate, Anatolia and southeastern Europe (Van der Made 1999; Koufos et al. 2005). Furthermore, the arrival in Europe of primates of African origin (e.g. Pliopithecus, Dryopithecus; Van der Made 1999) during the same interval of time shows that faunal exchanges between Africa and Europe, through southeastern Europe and Anatolia, were possible. In this context, without endemicity, the evolution of Lartetium in Northern Africa could have been linked to that of Europe, which would in turn explain the similarities with $L$. dehmi and $L$. prevostianum. It is also noteworthy that in this hypothesis, Beni-Mellal would be older than the mid-Miocene event (14.7 and 13.9 Ma; e.g. Flower and Kennett 1994; Holbourn et al. 2007), which is supported by our palaeoenvironmental interpretation, especially the occurrence of two species of Megaderma (a genus linked to tropical environments and also known associated with Lartetium in Lo Fournas II, MN6; Aguilar et al. 1986), whereas they no longer occur in more recent North African localities.

In any case, our study confirms that $L$. africanum is the oldest record of the family Soricidae in Africa and emphasises the potential of further studies and comparisons of the North African Soricidae with European and Anatolian ones as a key to establishing better biochronological calibrations.

\section{Conclusions}

Our detailed study of formerly undescribed material of Lartetium africanum makes it possible to justify its assignment to the genus Lartetium and to more precisely define its specific traits. Even if similarities between the genera Lartetium and Oligosorex exist, morphological differences between them justify the separation of the two genera. The habitat of $L$. africanum could be tropical and rather humid near a body of freshwater, which is in agreement with the sedimentary deposits, but associated vertebrate species also indicate more open and drier environments in the surroundings. Our comparisons of $L$. africanum with western European species suggest that Beni-Mellal could be older than previously proposed, possibly correlated with the European biozones MN5 or MN6. They also suggest that faunal exchanges 
between Africa and Europe occurring during the early Middle Miocene could have gone both ways. Progress in magnetostratigraphic studies is also necessary to obtain more precise datings of faunal exchanges between Africa and Eurasia.

Acknowledgements We are very grateful to have been invited to contribute to this issue and as such in being given the opportunity to honour our friend and colleague Albert van der Meulen in recognition of his highly valuable palaeontological studies. We thank D. Topa (Natural History Museum Vienna) for assistance in taking the scanning electron microscopy pictures. Gertrud Rössner (Munich) and Reinhard Ziegler (Stuttgart) are thanked for making available the Lartetium material under their care. G. Billet (MNHN Paris) is thanked for providing information on the holotype of L. africanum. Glyn Thoiron also kindly helped improve the English text. We also thank two referees, Raquel LópezAntoñanzas (University of Bristol) and Marc Furió (Institut Català de Paleontologia), and the guest editors of this issue, who contributed to this work through instructive discussions and comments on the manuscript.

\section{References}

Aguilar, J.-P., Calvet, M., Crochet, J.-Y., Legendre, S., Michaux, J., \& Sigé, B. (1986). Première occurrence d'un mégachiroptère ptéropodidé dans le Miocène moyen d'Europe (gisement de Lo Fournas-II, Pyrénées-Orientales, France). Paleovertebrata, 16, 173-184.

Benammi, M. (2006). New rodent localities in the continental Middle Miocene of Ait Kandoula basin (Morocco). Geobios, 39, 589-598.

Benammi, M., Calvo, M., Prévot, M., \& Jaeger, J.-J. (1996). Magnetostratigraphy and paleontology of Ait Kandoula Basin (high Atlas, Morocco) and the African-European late Miocene terrestrial fauna exchanges. Earth and Planetary Science Letters, 145, 15-29.

Brunet, J. (1961). Oiseaux. In R. Lavocat (Ed.), Le gisement de vertébrés miocènes de Beni-Mellal (Maroc). (pp. 105-108). Notes et Mémoires du service Géologique du Maroc, 155, 105-108.

Brunet, J. (1971). Oiseaux miocènes de Beni-Mellal (Maroc); un complément à leur étude. Notes et Mémoires du Service Géologique du Maroc, 237, 109-111.

Butler, P. M. (1998). Fossil history of shrews in Africa. In J. M. Wójcik \& M. Wolsan (Eds.), Evolution of shrews (pp. 121-132). Bialowieza: Polish Academy of Science, Mammal Research Institute.

Butler, P. M. (2010). Neogene insectivora. In L. Werdelin \& W. J. Sanders (Eds.), Cenozoic mammals of Africa (pp. 573-580). Berkeley: University of Columbia Press.

Choubert, G., \& Faure-Muret, A. (1961). Le gisement de vertébrés miocènes de Beni-Mellal (Maroc). Etude géologique. Notes et Mémoires du Service Géologique du Maroc, 155, 13-28.

Daams, R., \& Bruijn, H. de (1995). Classification of the Gliridae (Rodentia) on the basis of dental morphology. Hystrix, 6(1-2), 3-50.

Daams, R., \& Meulen, A. J. van der (1984). Paleoenvironmental and Paleoclimatic interpretation of micromammal faunal successions in the upper Oligocene and Miocene of North Central Spain. Paléobiologie Continentale, 2, 241-257.

Daams, R., Meulen, A. J. van der, Alvarez Sierra, M. A., PelaezCampomanes, P., \& Krijgsman, W. (1999). Aragonian stratigraphy reconsidered, and a re-evaluation of the Middle Miocene mammal biochronology in Europe. Earth and Planetary Science Letters, 165, 287-294.

Dannelid, E. (1998). Dental adaptations in shrews. In J. M. Wójcik \& M. Wolsan (Eds.), Evolution of shrews (pp. 157-174). Bialowieza: Mammal Research Institute, Polish Academy of Science.
De Bonis, L., Koufos, G. D., \& Sen, S. (1997). The Sanitheres (Mammalia, Suoidea) from the Middle Miocene of Chios Island, Aegean Sea, Greece. Revue de Paléobiologie, 16(1), 259-270.

Doukas, C. S., \& Hoek Ostende, L. W. van den (2006). Insectivores (Erinaceomorpha, Soricomorpha; Mammalia) from Karydia and Komotini (Thrace, Greece; MN 4/5). Beiträge zur Paläontologie, 30, 109-131.

Engesser, B. (1980). Insectivora und Chiroptera (Mammalia) aus dem Neogen der Türkei. Schweizerische Paläontologische Abhandlungen, 102, 47-149.

Engesser, B. (2009). The Insectivores (Mammalia) from Sansan (Middle Miocene, south-western France). Schweizerische Paläontologische Abhandlungen, 128, 1-91.

Fejfar, O., \& Sabol, M. (2005). Czech republic and Slovak republic. In L. W. van den Hoek Ostende C. S. Doukas, \& J. W. F. Reumer (Eds.), The fossil record of the Eurasian Neogene insectivores (Erinaceomorpha, Soricomorpha, Mammalia), Part I (pp. 51-60). Scripta Geologica, 5(1).

Flower, B. P., \& Kennett, J. P. (1994). The Middle Miocene climatic transition: East Antarctic ice sheet development, deep ocean circulation and global carbon cycling. Palaeogeography Palaeoclimatology Palaeoecology, 108, 537-555.

Furió, M., Santos-Cubedo, A., Minwer-Barakat, R., \& Agustí, J. (2007). Evolutionary history of the African soricid Myosorex (Insectivora, Mammalia) out of Africa. Journal of Vertebrate Paleontology, 27, 1018-1032.

Furió, M., Casanovas-Vilar, I., \& Hoek Ostende, L. W. van den (2011). Predictable structure of Miocene insectivore (Lipotyphla) faunas in Western Europe along a latitudinal gradient. Palaeogeography Palaeoclimatology Palaeoecology, 304, 219-229.

Hecht, M., Hoffstetter, R., \& Vergnaud, C. (1961). Le gisement de vertébrés Miocènes de Beni-Mellal (Maroc). Amphibiens. Notes et Mémoires du Service Géologique du Maroc, 155, 103.

Heissig, K. (1989). Neue Ergebnisse zur Stratigraphie der mittleren Serie der oberen Süßwassermolasse Bayerns. Geologica Bavarica, 94, 239-257.

Heizmann, E. P. J., \& Fahlbusch, V. (1983). Die mittelmiozäne Wirbeltierfauna vom Steinberg (Nördlinger Ries). Eine Übersicht. Mitteilungen der Bayerischen Staatssammlung für Paläontologie und Historische Geologie, 23, 83-93.

Hilgen, F. J., Lourens, L. J., Dam, J. A. van, Beu, A. G., Boyes, A. F., Cooper, R. A., et al. (2012). Chapter 29 - the Neogene period. In F. M. Gradstein, J. G. Ogg, M. Schmitz, \& G. Ogg (Eds.), The geologic time scale 2012 (pp. 923-978). Amsterdam: Elsevier.

Hoek Ostende, L. W. van den (2001). Insectivore faunas from the Lower Miocene of Anatolia - Part 6: Crocidosoricinae (Soricidae). Scripta Geologica, 122, 47-81.

Hoffstetter, R. (1961). Le gisement de vertébrés miocènes de Beni-Mellal (Maroc). Squamates. Notes et Mémoires du Service Géologique du Maroc, 155, 95-101.

Holbourn, A., Kuhnt, W., Schulz, M., Flores, J.-A., \& Andersen, N. (2007). Orbitally-paced climate evolution during the middle Miocene "Monterey" carbon-isotope excursion. Earth and Planetary Science Letters, 261, 534-550.

Hugueney, M., \& Maridet, O. (2011). Early Miocene soricids (Insectivora, Mammalia) from Limagne (Central France): new systematic comparisons, updated biostratigraphic data and evolutionary implications. Geobios, 44, 225-236.

Hugueney, M., Mein, P., \& Maridet, O. (2012). Revision and new data on the Early and Middle Miocene soricids (Soricomorpha, Mammalia) from Central and South-Eastern France. In L. Costeur, \& O. Maridet (Eds.), A tribute to Burkart Engesser (pp. 23-49). Swiss Journal of Palaeontology, 131(1).

Jaeger, J.-J. (1977). Les Rongeurs du Miocène moyen et supérieur du Maghreb. Palaeovertebrata, 8(1), 1-164. 
Kälin, D., \& Kempf, O. (2009). High-resolution stratigraphy from the continental record of the Middle Miocene Northern Alpine Foreland Basin of Switzerland. Neues Jahrbuch für Geologie und Paläontologie, Abhandlungen, 254, 177-235.

Klietmann, J., Nagel, D., Rummel, M., \& Hoek Ostende, L. W. van den (2014). Heterosorex and Soricidae (Eulipotyphla, Mammalia) of the fissure Petersbuch 28; micro-evolution as indicator of temporal mixing? Comptes Rendus Palevol, 13, 157-181.

Koufos, G. D. (2006). The Neogene mammal localities of Greece: faunas, chronology and biostratigraphy. Hellenic Journal of Geosciences, $41,183-214$.

Koufos, G. D., Kostopoulos, D. S., \& Vlachou, T. D. (2005). Neogene/ Quaternary mammalian migrations in Eastern Mediterranean. Belgian Journal of Zoology, 135(2), 181-190.

Lavocat, R. (1961). Le gisement de vertébrés miocènes de Beni-Mellal (Maroc). Etude systématique de la faune de mammifères et conclusions générales. Notes et Mémoires du Service Géologique du Maroc, 155, 29-94, 52-67, 109-144.

López-Antoñanzas, R., \& Knoll, F. (2011). A comprehensive phylogeny of the gundis (Ctenodactylinae, Ctenodactylidae, Rodentia). Journal of Systematic Palaeontology, 9(3), 379-398.

López-Antoñanzas, R., Sen, S., \& Koufos, G. (2005). A ctenodactyloid rodent (Mammalia, Rodentia) from the Middle Miocene of Chios Island (Greece). Geobios, 38, 113-126.

López-Guerrero, P., Oliver-Pérez, A., Álvarez-Sierra, M. A., GarcíaParedes, I., Hoek Ostende, L. W. van den, \& Peláez-Campomanes, P. (2007). Paleontology of the Aragonian Casa Montero (Madrid) vertebrates fossil site. In O. Cambra-Moo, C. Martínez-Pérez, B. Chamero, F. Escabo, D. S. Esteban-Trigno, \& J. Marugán-Lobón (Eds.), Cantera paleontológica (pp. 247-254). Cuenca: Diputación Provincial de Cuenca.

Made, J. van der (1999). Intercontinental relationship Europe-Africa and the Indian subcontinent. In G. E. Rössner \& K. Heissig (Eds.), The Miocene land mammals of Europe (pp. 457-472). Munich: Verlag Dr. Friedrich Pfeil.

Maridet, O., \& S. Sen (2012). Les Cricetidae (Rodentia) de Sansan. In S. Peigné, \& S. Sen (eds), Mammifères de Sansan (pp. 29-65). Mémoires du Muséum d'Histoire Naturelle de Paris, 203.

Marković, Z., \& Milivojević, M. (2010). The Neogene small mammals from Serbia - collection methods and results. Bulletin of Natural History Museum, 2010, 105-114.

Mein, P. (1975). Résultats du groupe de travail des vertébrés: Biozonation du Néogène méditerranéen à partir des mammifères. In J. Senes (Ed.), Report on activity of the RCMNS working groups (19711975) (pp. 78-81). Bratislava: RCMNS.

Mein, P., \& Ginsburg, L. (2002). Sur l'âge relatif des différents dépôts karstiques miocènes de La Grive-Saint-Alban (Isère). Cahiers Scientifiques du Musée d'Histoire Naturelle de Lyon, 2, 7-47.

Meulen, A. J. van der, García-Paredes, I., Alvarez-Sierra, M. A., Hoek Ostende, L. W. van den, Hordijk, K., Oliver, A., et al. (2011). Biostratigraphy or biochronology? Lessons from the early and middle Miocene small mammal events in Europe. Geobios, 44, 309 321.

Meulen, A. J. van der, Garciá-Paredes, I., Àlvarez-Sierra, M. A., Hoek Ostende, L. W. van den, Hordijk, K., Oliver, A., \& PeláezCampomanes, P. (2012). Updated Aragonian biostratigraphy: small mammal distribution and its implications for the Miocene European chronology. Geologica Acta, 10, 1-24.

Meulenkamp, J. E., \& Sissingh, W. (2003). Tertiary palaeogeography and tectonostratigraphic evolution of the Northern and Southern PeriTethys platforms and the intermediate domains of the AfricanEurasian convergent plate boundary zone. Palaeogeography Palaeoclimatology Palaeoecology, 146, 209-228.

Pickford, M. (2012). Les Suoidea (Artiodactyla) de Sansan: Systématique, paléoécologie, biogeographie et biochronologie. In
S. Peigné, \& S. Sen (eds), Mammifères de Sansan (pp. 249-278). Mémoires du Muséum d'Histoire Naturelle de Paris, 203.

Pickford, M., Wanas, H., Mein, P., \& Soliman, H. (2008). Humid conditions in the western desert of Egypt during the Vallesian (Late Miocene). Bulletin of the Tethys Geological Society, 3, 63-79.

Prieto, J., Böhme, M., Maurer, H., Heissig, K., \& Abdul Aziz, H. (2009). Biostratigraphy and sedimentology of the Fluviatile Untere Serie (Early and Middle Miocene) in the central part of the North Alpine Foreland Basin: implications for palaeoenvironment and climate. International Journal of Earth Sciences, 98, 1767-1791.

Rage, J. C. (1976). Les Squamates du Miocène de Beni-Mellal, Maroc. Géologie Mediterranéenne, 3(2), 57-69.

Reichenbacher, B., Krijgsman, W., Lataster, Y., Pippèrr, M., Van Baak, C. G. C., Chang, L., Kälin, D., Jost J., Doppler, G., Jung, D., Prieto, J., Aziz, H.A., Böhme, M., Garnish, J., Kirscher, U. \& Bachtadse V. (2013). A new magnetostratigraphic framework for the lower Miocene (Burdigalian/Ottnangian, Karpatian) in the North Alpine Foreland Basin. In D. Marty, D. Becker, C. Pirkenseer, K. Grimm, \& L. Cavin (eds.), A tribute to the late professor Jean-Pierre Berger (pp. 309-334). Swiss Journal of Geosciences, 106.

Reumer, J. W. F. (1984). Ruscinian and early Pleistocene Soricidae (Insectivora, Mammalia) from Tegelen (The Netherlands) and Hungary. Scripta Geologica, 73, 1-173.

Reumer, J. W. F. (1995). The evolution of shrews (Mammalia, Soricidae) a key role for humidity. Geobios, 28, 367-372.

Rummel, M. (2000). Die Cricetodontini aus dem Miozän von Petersbuch bei Eichstätt. Die Gattung Cricetodon. Senckenbergiana lethaea, 80, 149-171.

Rummel, M., \& Kälin, D. (2003). Die Gattung Cricetodon (Mammalia, Rodentia) aus dem Mittelmiozän der Schweizer Molasse. Zitteliana, A43, 123-141.

Sach, V. J. (1999). Litho- und biostratigraphische Untersuchungen in der Oberen Süßwassermolasse des Landkreises Biberach a. d. Riß (Oberschwaben). Stuttgarter Beiträge zur Naturkunde, B276, 1167.

Sach, V. J. (2014). Fossilien Katalog der Oberen Süßwassermolasse (OSM), Brackwassermolasse (BM), Oberen Meeresmolasse (OMM) und der Unteren Süßwassermolasse (USM) in Südwestdeutschland. Documenta Naturae, Sonderbände, 70, 1-115.

Sen, S. (1977). Megapedetes aegaeus n. sp. (Pedetidae) et à propos d'autres "rongeurs africains" dans le Miocène d'Anatolie. Geobios, 10(6), 983-986.

Sen, S. (1997). Magnetostratigraphic calibration of the European Neogene mammal chronology. Palaeogeography Palaeoclimatology Palaeoecology, 133, 181-204.

Stehlin, H. G. (1940). Zur Stammegeschichte der Soriciden. Eclogae Geologicae Helveticae, 33(2), 299-306.

Stoetzel, E. (2013). Late Cenozoic micromammal biochronology of northwestern Africa. Palaeogeography Palaeoclimatology Palaeoecology, 392, 359-381.

Tesón, E., Pueyo, E. L., Teixell, A., Barnolas, A., Agustí, J., \& Furió, M. (2010). Magnetostratigraphy of the Ouarzazate Basin: implications for the timing of deformation and mountain building in the High Atlas Mountains of Morocco. Geodinamica Acta, 23(4), 151-165.

Vergilino, M. (1999). Les peuplements de Soricidae (Lypotyphla, Mammalia) du Maghreb depuis le Miocène. Unpublished DEA Dissertation, University Montpellier 2, France.

Werdelin, L. (2010). Chronology of Neogene mammal localities. In L. Werdelin \& W. J. Sanders (Eds.), Cenozoic mammals of Africa (pp. 28-43). Berkeley: University of Columbia Press.

Wessels, W. (2009). Miocene rodent evolution and migration Muroidea from Pakistan, Turkey and Northern Africa. Geologica Ultraiectina, 307, 1-290.

Winkler, A. J. (1992). Systematics and biogeography of middle Miocene rodents from the Muruyur Beds, Baringo District, Kenya. Journal of Vertebrate Paleontology, 12(2), 236-249. 
Ziegler, R. (1989). Heterosoricidae und Soricidae (Insectivora, Mammalia) aus dem Oberoligozän und Untermiozän Süddeutschlands. Stuttgarter Beiträge zur Naturkunde, B154, 173.

Ziegler, R. (1998). Wirbeltiere aus dem Unter-Miozän des LignitTagebaues Oberdorf (Weststeirisches Becken, Österreich): 5.
Marsupialia, Insectivora und Chiroptera (Mammalia). Annalen des Naturhistorischen Museums in Wien, 99 A, 43-97.

Ziegler, R. (2006). Miocene insectivores from Austria and Germany - an Overview. Beiträge zur Paläontologie, 30, 481-494.

Ziegler, R., \& Fahlbusch, V. (1986). Kleinsäuger-Faunen aus der basalen Oberen Süßwasser-Molasse Niederbayerns. Zitteliana, A14, 3-58. 